\title{
The Long-Lasting Gender: Cases of the Female Legendary Spirits on Indonesia Stories
}

\author{
Resti Nurfaidah \\ \{sineneng1973@gmail.com\} \\ West Java Language Agency, Jalan Sumbawa 11, Kota Bandung
}

\begin{abstract}
Unconsciously, those gender based events have occurred long ago, even since our ancestors had not recognize the writing yet. So, actually, gender is not a new thing. Eventhough, among other, this paper will discuss those events that occur in various Indonesian literature, especially those which related to gender injustice of some female spirits, such as Kuntilanak, Wewe Gombel, Nyi Roro Kidul, and so on. This research is a descriptive study with literary anthropology and gender study approach which is focused into these following points: (1) how female spirits are represented in literature, (2) what conflicts that they are deal with, and (3) what endings that they found. Hypotheses indicate that female spirits had transformed from bad empirical experiences, especially the patriarchal conflicts that made them being subordinated. As a solution, in the end of lifes, they sacrificed themselves and then were transformed into the weak or strong spirits.
\end{abstract}

Keywords: Gender; Anthropology; Spirits

\section{Introduction}

As social beings, humans are born and grown up in a location filled with the values they believed in. These values are vertically conveyed, of course, from one generation to another. One of the moral values conveyed is found in oral tradition: sending messages or values through speech acts. Oral literatures, as a part of the tradition, contains various themes, among others, stories in the form of fables, histories, or real and unreal things, such as spirits. Armstrong [1] said that humans are myth producers. Humans and their natural environment around them have long tight relationship [2] [3]. Sumardjo [4] ) said that Sundanese people, for example, strongly believe in the relationship between Sari Pohaci and the paddy. Rozak [5] conveyed the views of the Sunda Wiwitan, old Sundanese belief, on the myth of the stages of the creation of natural objects that God created before the creation of humans.

Humans [1] have been long believed that there is great power behind the creation of the nature properties: stone, mountain, river, water spring, etc. So, there must be a powerful creator-even the most. As a little part of the nature, humans are naturally well-equipped with consciousness of give thanks the Creator. Indonesia is rich in myths and legends about subtle creatures, both those that have been known as a legendary 
creatures: Kuntilanak, Wewe Gombel, or Nini Anteh; or other from contemporary era: Sumiati. Their appearance risen many myths associated with their supernatural powers on human life. However, this paper will be focused on examining the anthropological sides of experiences of their social role, both before and after their transformations. Endraswara [6] said that anthropological literary seeks to examine attitudes and behaviors that emerge as culture in literary works. Both anthropology and literature, said Endraswara [6], are very close because they are focused on human life studies [7].

Although, sometimes we are a little bit difficult to distinguish that phenomena are realistic or just fantastic. At least Endraswara [6] underlined the following two things, related to the closeness itself: 1) literature and anthropology have close research objects that lead to the phenomenon of the reality of human life; 2) literature and anthropology have methodological affinities, meaning that both of them use a lot of interpretations of symbolic phenomena; 3) literature and anthropology tend to maintain the concept of kinship (breed) as a symbol of the context of life. Endraswara said that studying literature from the anthropological perspective will open the eyes of literary scholars to symbolic phenomena.

Harini, and Rostiyati [8] in "Education of Sundanese Women in the Story of Nini Anteh" described academic concepts on Nini Anteh. Several important points were conveyed by Harini and Rostiyati, among others, the main motive in Nini Anteh was the fulfillment of desires; relations between figures are a form of gender equality [9]; and the fulfillment ability was accompanied by the possession of saepi knowledge. There were several functions of of Nini Anteh story, such as a reflection of local cultural identity or a mirror of wishful thinking.

\section{Methodology}

This research is a qualitative that explores matters relating to female spirits which have been believed to have their origins from generation to generation, then associated with gender-related events that had occur as the cause of the emergence of these creatures. To study those spirits, the author used an anthropological approach. Data collection was carried out by observing and paying close attention to various pages and uploads in the digital world related to the origins and beliefs of these spirits. Then, focusing into things that were believed to be the grievest background for these spirits. The data were taken from sources in books, innovative books about spirits and several literary works that were inspired by people's beliefs, among others, Bumi Kuntilanak (Denny Herdy and Standza), Gerbong Dialog Danur (Risa Saraswati), and Bausastra Lelembut (Assattari, et. al.).. In addition to manual data, the author also uses digital sources, such as journal papers, articles, or videos about these spirits. Based on both sources, the authors carried out processing steps based on the anthropological approach by considering cultural aspects, especially people's beliefs that never fade about these spirits, emphasizing on the gender aspect which is the focus of the research. The final step of the research is reporting through this article.

\section{Result and Discussion}


The following discussion covered myths of legendary figures: Kuntilanak, Sumiati, Nyi Roro Kidul, Wewe Gombel, or Kelong Wewe, Nini Anteh. The discussion began with character descriptions from various versions, including data in the form of literary works and references. Furthermore, the analysis was landscaped by anthropological concepts to draw a relation on the role of gender in the life of the following legendary figures.

\subsection{Kuntilanak}

Kuntilanak is a female ghost that is represented on many media as a woman with a very bad appearance. Her face is very ugly, covered with long hair, bad smell, sometimes is represented with a large hole on her back. Rori[10], said that Kuntilanak came from a tragic incident that came into a woman's life, Ngatirah. Ngatirah was the twentieth wife of a powerful shaman, $\mathrm{Ki}$ Bamantara. They lived in a remoted village called Balangandang. The incident was happened long before the colonial era. Ki Bamantara was so powerful that made the people in the village were very afraid of him. He really crazy of the jaipongan performance. He obliged all residents to watch the program, no matter who-children or the elderly. One day something very surprising happened. In the show, one of the jaipong dancers was trance. Ki Bamantara approached the dancer, then touched her forehead and chanted a spell. Suddenly, the dancer got up with an angry face and red eyes, saying, "This time you will be hurt." Ki Bamantara became furious and wanted to pull out his dagger. However, he saw a golden carriage that Nyi Roro Kidul was riding suddenly appeared from behind the trees. Surprisingly, the dancer who had been trance approached and got into the carriage, and sat beside the Lord of the Southern Seas. The carriage then disappeared so fast along lightning strikes. The show was totally disbanded.

$\mathrm{Ki}$ Bamantara entered the house and told his wife that there was one mistake he had made in the ritual. He decided to go to a sacred tomb, his father's grave. Before going to that place, Ki Bamantara performed a ritual ceremony. Sunaryo, one of the residents who had deep grudge against Ki Bamantara, saw the magic man's departure into the forest. Sunaryo lost his wife because her refusal of seeing the Jaipong show. The next day, Sunaryo's wife vomited glass, as often happens to other residents who were reluctant to watch the show. Sunaryo followed Ki Bamantara. The man performed a ritual at his father's grave. Thick smoke rose from the tomb and made Sunaryo surprised to see it. He tried to stay away from that place. However, suddenly Ki Bamantara was in front of him. Sunaryo was scared and ran fast.

Ki Bamantara let Sunaryo go, then resumed performing the ritual. His dream gave him a clear insight that Nyi Roro Kidul was angry. There was a grudge from one of Nyi Roro Kidul's descendants named Santika, one of the jaipong dancer on the late show. Ki Bamantara realized that he would not be able to face the power of the ruler of the southern seas. From his father spirit. he got instructions to immediately hold a ritual ceremony on the seafront.

On the other hand, Sunaryo studied one of the darkest and dangerous mistique, namely waringin sungsang. He was imprisoned in a very haunted cave and was located on the beach, on of Nyi Roro Kidul's teritories. In the cave, he obediently learned the darkness despite being massively disturbed by various mystique creatures. On the last night, he was visited by a wickedst kunyang. He was bounced and his mouth opened. The Kunyang got into his body. When he woke up, he was already in his hut. He grabbed a 
small doll that had once been used to cast a spell on Ki Bamantara. But mostly it was commonly failed. This time, he was successful. He stabbed the doll's body many times, in the same time, in another place, Ki Bamantara got pain. He embraced one of his heirloom kris, but it was totally failed. He got bounced and was unconscious. There were red bumps all over his body.

Ngartasih, Ki Bamantara's wife, suspected that her husband had been witched. None of the neighbors wanted to help him because their family was being hated by the villagers. One day, Mbok Rumi, a mysterious woman who always visits Ki Bamantara's house, arrived. Mbok Rumi said that she would be pregnant. Regarding her husband, Ngartasih was told that her husband would be fine. Elsewhere, Sunaryo had disappointed that $\mathrm{Ki}$ Bamantara was still alive. Sunaryo came to Ki Bamantara's residence and intended to kill the man. Unfortunately, he had failed. Sunaryo met his end. The Kunyang contained in his body was actually destroyed by Ki Bamantara. Sunaryo's body was laid on the beach. Ki Bamantara then hold the ritual. Suddenly the Nyi Roro Kidul palace appeared. The ruler of the sea said that his illness was a curse from him. To free it, he must give sacrifices to the ruler of the sea. Besides, Ngartasih's pregnancy made him happy. However, the fetus was asked by the ruler of the sea. Ki Bamantara objected. The ruler of the sea agreed his refusal. But he had to make up for it at the expense of 40 children in Balangandang village. She gave Ki Bamantara seeds to be planted behind the house of the potential victims. The seed was a sign for the picker of the victims. The village then lost many small children and became a commotion. The villagers attacked. The resistance was carried out even though it was tough. Not a few victims who fell. Ki Bamantara's house was burned. The man's body then laid helpless. Residents also tied the man's body and shaved his armpit hair as a source of his strength all this time. Then, Ki Bamantara was brutally murdered.

Ngartasih fled into the forest. In the middle of the forest, he gets help from Mbok Rumi. Mbok Rumi took care of Ngartasih until she gave birth to a baby girl named Sekar. One day, by accident, some Balangandang villagers found Ngartasih and snatched Sekar from the woman's hands. At that time Mbok Rumi was looking for firewood. When he returned, he was surprised to see the state of Ngartasih and then Sekar who had become corpses. Mbok Rumi then allied with the devil. She hold the rite. Mbok Rumi sliced his hand with a small knife and poured her blood on the poor woman's body. A herd of demons entered Ngartasih's body. The woman then disappeared. Mbok Rumi was surprised to see Ngartasih's transformatins. She was wearing a white robe with long flowing hair while singing the song "Lingsir Wengi". "Lingsir Wengi" is a popular song in the Kuntilanak. The song is considered to be written by Sunan Kalijaga as a rebuke of reinforcements. There were pros and cons because of its creationing. Ones said that it is trully his song, but others said not.Soon, Ngartasih approached Mbok Rumi and killed the old woman. After that, he disappeared. A week later, Balangandang Villagers experienced severed disturbances. Ngartasih avenged her husband's death and killed many of the villagers. The village, then, turned into a deserted village after being left by some of the survivors. Ngartasih was considered the forerunner of kuntilanak in the archipelago. Ngartasih's descendants had spread throughout the place.

It's different from Omara's view. In his upload, Omara [11] said that the word kuntilanak comes from the Malay language, namely Pontianak or puntianak. This creature is a ghost that comes from a woman who died during childbirth. Pontianak itself stands for women who die with children. At the time of the establishment of the palace, Sultan Syarif Muhammad was disturbed by these creatures. The area is called Pontianak. 
The people of Pontianak, have a belief that the origin of Pontianak comes from the punti tree or tall tree. For Javanese people, kuntilanak likes to disturb pregnant women. Therefore, pregnant women are advised to bring sharp objects, such as nails, scissors, razors. Assattira et. al. [12] adds that the kuntilanak is a female ghost who has failed in giving birth. She died with the baby still in her womb. He likes to stay in a tree or other quiet place while laughing or crying. In the Ensiklopedia Dunia [13], Kuntilanak is described as very universal. Not only in the Archipelago, but in Southeast Asia also has myth of this creature. In Malaysia, Kuntilanak is believed to like to kill humans by sucking the blood of its victims from the nape of the neck, like a vampire. Kuntilanak is also described as often attacking men who are not introspective. Its presence is usually accompanied by the scent of frangipani flowers. In the Sundanese, the kuntilanak is not described as having a gaping hole on its back.

Besides wearing white clothes, there is also a kuntilanak who is depicted wearing red clothes. Assattira et. al. [12] describes that the red kuntilanak comes from women who died after giving birth. Not infrequently he still has fragments of memories of when he was alive. The red color of her dress will glow more and more like the emotions and memory power increase. However, if it has subsided, the red color will fade again. Herdy conveyed another characteristic of the kuntilanak, apart from living in trees and places that tend to be quiet and dark. In "Kuntilanak", Herdy [14] said that kuntilanak likes to disturb and bind weak women. The character of Teh Enok is a skilled worker in a garment factory so he is very loved by his superiors. The attitude of their superiors who often praised Enok Tea, and cursed the girls' colleagues, caused them to hate themselves. Teh Enok became gloomy after realizing the drastic attitude of his colleagues. Since then, he is often like possessed until unconscious. Teh Enok suffered more and more and his body began to shrink. Like it or not, he had to stop working. His marriage also foundered. His parents' efforts were in vain. Enok tea, according to smart people, possessed kuntilanak. The spirit slowly locked the mind and also the woman's self. One day, Teh Enok's sanity level hit rock bottom. He ran away and disappeared. Enok tea was never found again. Saraswati [15] in "Danur Kasih" conveys another variant of kuntilanak, in the form of a ngesot ghost. The subtle creature that moves by crawling is said to be the incarnation of a woman who has experienced a sad event during her life. Love went to the city of Bandung to try her luck. She was accepted to work as a domestic helper in a fairly good family. At first, Kasih's life went smoothly until he met Karman, a motorcycle taxi driver. Karman is skillfully able to subdue Kasih, an innocent girl. The girl could be ensnared and lost her chastity. Love then became pregnant, while Karman gradually argued and left her. Love has to bear the shame, both to herself, her family in the village, and her employer's family. In the end, Love was unable to solve the problem, so decided to hang herself. Death is not the best way. The torture for his actions in the form of suicide, tortured him greatly, even hundreds of times more than the pain he suffered when he took his life. It cannot stand, it can only crawl. He is looking for someone who can release the rope around his neck until he meets Risa. Too bad, Risa couldn't open the rope that was getting tighter and tighter and suffocating her breath. Love continues to live as a very tormented spirit.

\subsection{Sumiati}

Sumiati is a female figure similar to a kuntilanak. However, there is one difference between the two, namely, the color of the dress that Sumiati wears will vary according to 
the highs and lows of emotions experienced by the creature. in a calm state, her dress will be white, on the other hand, if her emotions are high, her dress will turn red. In several uploads in cyberspace, Sumiati is recognized as a spirit creature found in the Makassar area. Aziz, Nurul, and Ireng [16], Sumiati is told as a girl who is betrothed to a young man chosen by her parents, named Fadli. Both live happily. Fadli worked as a crew member. His break with Sumiati was only one week. Fadli brought his bride to Makassar. The goal is to make it easier for Fadli to return home after completing his duties at sea. Unfortunately, Fadli had an accident the night before departure. Fadli's motorbike was crucified by a big motorbike rider. Fadly fell. However, he just smiled and didn't mind the accident because he was more concerned with his memory of Sumiati who was waiting for him at home. Fadly drove back to the house. However, the big motorbike rider and his entourage did not accept Fadly's attitude even though the sailor's motorbike was also damaged. They attack Fadly to death.

Later, after receiving news from related parties, Sumiati screamed hysterically. He experienced great sadness. After the death of her husband, Sumiati was often pensive. If longing torments her, Sumiati will hug her husband's photo, or hug a torn shirt decorated with her husband's dried blood at the time of the accident, or go around on her husband's motorbike. However, as with her husband, one night, Sumiati had to experience something quite terrible. It was a lonely road. Suddenly he runs into a group of young men who then brutally sexually harass him. Not only that, Sumiati also suffered extraordinary physical torture until her collarbone was broken, as well as severe damage to the pubic area. Sumiati is killed and her body is arbitrarily buried. Later Sumiati wakes up and does not understand that she is dead. He walked a long way to his house. He was surprised because he could not feel the weight of the lock on the house he rented and when it penetrated the door of the house. She took a photo of her husband and Sumiati was crying. The revenge inside Sumiati peaked. The faces of her husband's persecutors appeared. He began to target members of the large motorcycle group. One by one they were harmed to their death. The police find it difficult to resolve the case of the death of the motorcycle group. All these deaths show things that are beyond human understanding.

After that, Sumiati went to her husband's grave and told all the things she did. She hoped that her husband would give her an answer. However, Sumiati had to swallow a deep disappointment because only a gust of wind reacted to her. Sumiati then returns to her tomb. For several years, he only walked from the two graves, the location of the rape and the location of his burial. Sumiati feels very lonely. He plans to take the same revenge against the perpetrators of sexual harassment against him. Unfortunately, he couldn't remember the full picture of the perpetrator, except for the color of the clothes they were wearing. Sumiati never stopped her search throughout the Makassar area. If a woman is in a trance, she will claim to be Sumiati while crying. He often appeared at several places in the area or waved his hand at the big bikers. Unlike Aziz, Nurul, dan Ireng [16] , Assattira [12] said that Sumiati was a legendary ghost from Java, see at pp. $176-177$.

\subsection{Nyi Roro Kidul}

Nyi Roro Kidul is a legend from the island of Java. However, in subsequent developments, it is also recognized by the North Sumatra as one of its[17] legendary figures [17]. He is known as Si Boru Biding Laut, and is considered the first daughter of 
Guru Tatea Bulan, the first son of the Batak King. In general, Nyi Roro Kidul is a daughter of King Padjadjaran. Many versions [18] relate to Nyi Roro Kidul's father, namely Prabu Mundingsari, Prabu Munding Wangi, or Prabu Siliwangi. In another version, he is said to be a descendant of the Kingdom of Kediri or the Kingdom of Kahuripan. Nyi Roro Kidul is a princess who has to suffer an unlucky fate and, later, transforms the ruler of the South Seas. Regarding this transformation, there are many versions, including the princess's decision to throw herself into the sea because of a curse in the form of skin disease from her stepmother; a victim of jealousy of a young wife; refusing to be married off to anger the king and banish him from the palace; as well as the curse of skin disease that appears on the wedding night. Meanwhile, some said that Nyi Roro Kidul had a disgusting skin disease that forced her to stay away from the palace and meditate in the forest; imprisoned to approach the Almighty and gain strength, and some mention self-isolation as a form of rejection of the matchmaking carried out by his parents. Dipping into the sea also invites many versions, among others, after completing meditation, he goes to a cliff by the sea and throws himself into the seawater with very powerful waves, and he will become the ruler of the South Sea. In another version, after experiencing disappointment, Nyi Roro Kidul went to the beach and heard a magical whisper that she had to plunge into the fierce waves of the ocean if she wanted her beautiful face back, and would be made the ruler of spirits. In another version, Nyi Roro Kidul lost in court and was sentenced to exile into the forest as a consequence of her parents' rejection of an arranged marriage.

Another version relates to the birth of Nyi Roro Kidul as a princess from the Galuh Kingdom. When she was just born, Nyi Roro Kidul could talk and convey to the residents of the kingdom that she was Ratu Ayu, the ruler of spirits throughout Java and her throne was in the South Sea. In another version, after that, the long-dead King Sindhula reappears and says that the baby is the future ruler of the kingdom and he will not have a husband for the rest of his life. Later, however, a Muslim ruler on the island of Java would become her husband. Panembahan Senopati, the ruler of the Kingdom of Mataram II, is described as having extraordinary power. It was this power that caused Nyi Roro Kidul to feel awe so that she was willing to meet the man. Both are attracted to each other and make love. Nyi Roro Kidul invites her lover into the underwater kingdom. The ruler of the sea believed that his lover and descendants would one day become rulers of Java.

\subsection{Wewe Gombel or Kelong Wewe}

There is a story about a girl named Sri who is very beautiful [19]. He met Jaka, a handsome and well-to-do man. Sri's presence was not approved by Jaka's mother because the girl was just an ordinary man. However, Jaka managed to convince Sri and invited her to the aisle even though her mother objected. Jaka and Sri's life was happy. However, after that, Jaka often received insults from his friends that he was a less powerful man. Jaka then often did rude things to Sri. One day the mother introduced another woman for Jaka to marry. Jaka is also happy with his new wife to have children. Meanwhile, the insults and torture for Sri continued to occur. Until finally, out of control, Sri took a knife and stabbed her husband and mother-in-law to death. He took the baby and fled into the forest. Originally he wanted to jump into the abyss with the baby. However, he gave up his intention. Sri returned the baby to its mother, who was in pursuit with the residents. After that, he jumped into the abyss. Since then, the legend about Wewe 
Gombel has emerged. The word Gombel is taken from the name of a hill in Semarang. Wewe Gombel never did any harm to children, the target victims. However, she wants to take care of the children she kidnapped. The community believes that children who are victims of Wewe Gombel are children who are outside or lack parental supervision.

Wewe Gombel's story can also be read in an interesting story written by Herdy [20], entitled "Dunia Setelah Senja" (The World After Dusk). Herdy describes a girl who was born and grew up in a broken family. His father was a contractor with many wives and children. All family members live in one house. Interpersonal relationships that are not well established with very loose supervision, cause the girl to be sexually abused since childhood by her step-sister. Of course, he didn't dare to tell his father about it. Communication with his brothers also tends to be stiff. He hides more deeply all the problems he experienced. Over time, people at home thought he was crazy because he liked to talk as if he had someone to talk to. Until one time, he met Wewe Gombel who was able to give him sincere affection. He plays with a herd of spirits that can make him laugh. Wewe Gombel's kindness made him consider her a mother. Vice versa. He felt the warmth of a mother's embrace in the truest sense. He didn't want to go home. Meanwhile, from the direction of the village, voices pounded. The kiai and a group of students recited the holy verse. The tranquility of Kuta Gandok was greatly disturbed. The little girl's favorite spirits ran because they couldn't stand the holy verse they were reading. After that, the girl was found in a bamboo grove. He felt very sad. Years later, he grows up to be a cold teenager but likes to talk to invisible people. Then, he waited for the full moon to come. He wanted to go to Kuta Gandok. However, he was met with disappointment because the place had now been reduced to a spacious area with a sign below: Will Be Built Real Estate!. The despair he couldn't hold back drove him to one goal: to die. He jumped into the abyss below.

\subsection{Nini Anteh}

Nini Anteh is a Sundanese folk tale. Various versions [21] [22] [23] [8] [24]have emerged regarding the origin of Nini Anteh. One of the full versions can be found on the following fairy tale.org page. One day, in the Pakuan Kingdom, a beautiful baby girl was born from the belly of the queen's favorite lady. Unfortunately, the baby did not get to see his mother. The lady died shortly after giving birth. The Queen then took care of Anteh, the name of the baby, and got the same affection as the crown princess, Princess Endahwarni. Nevertheless, Anteh grew up as a girl who knew herself, was polite and had great respect for the ruler of the kingdom. Anteh and Endahwarni lived in harmony until one day, an incident occurred that broke them. The Queen and King of the Pakuan Kingdom intend to match Endahwarni with Prince Antakusumah, a mighty nobleman. Princess Endahwarni accepted the match. When Prince Antakusumah visited the kingdom, he saw Endahwarni very beautifully. However, he then saw Anteh looking much prettier. In short, the Prince loves Anteh. After that, unenthusiastically, the prince was forced to propose to Endahwarni. Endahwarni did not know that. He asked Anteh to stay away from his side. Moreover, the prince seemed to want Anteh.

Anteh decided to return to his mother's village. He met his uncle who immediately recognized Anteh because of the resemblance of the girl's face to her late mother. Anteh lives quietly with his uncle. He helped his uncle by becoming a tailor. More and more, the results of the stitches are very famous. Anteh also married, had children, and lived happily. Unexpectedly, a golden carriage arrived in front of his house. Apparently, Putri 
Endahwarni was full of regret looking for Anteh everywhere. Now she has become a Queen of the Pakuan Kingdom. He regrets his actions in the past and asks Anteh and his family to move to the palace. Anteh was assigned as a palace tailor. Anteh's move to the palace invites Antakusumah's curiosity, who has not been able to get rid of her love for Anteh. One day, he came to Anteh. Anteh tried to dodge. He kept running while hugging his beloved cat named Candramawat. The Prince then chased him to the edge of a cliff. Desperate Anteh, begged the power to save him. Suddenly, Anteh felt her body attracted by the moonlight. Anteh realizes that he no longer lives on earth, but the moon. To relieve her sadness, she weaves a long cloth that can reach the earth. However, the cloth can never reach the earth because it is always torn and damaged by Candramawat.

In the version of Rahmadhita, et. al. [23] it is said that Anteh fled to the forest because he was being chased by Prince Antakusuma while carrying Candramawat. Endahwari, who swallowed the disappointed attitude of her husband, then often looked at the moon and hoped that Anteh would come down to earth. For decades later, Endahwarni constantly weaves a long cloth that is increasingly able to reach the moon. Endahwarni walked on the stretch of cloth. On the other hand, Anteh while holding her cat down from the moon. Endahwarni ran to hug Anteh and expressed her regret. He asked Anteh to return to earth. The two friends returned to the Pakuan Kingdom. Endahwarni then expelled her husband. Karomah [24] stressed that Dutch writer CM Pleyte more than a hundred years ago wrote the story of Nyai Anteh in the form of a short story in his book entitled "De Inlandsche Nijverheid West Java Sociaal-ethnologist Verschijnsel", published in 1912. CM Pleyte's title is Nyai Anteh was changed into Dutch to become Grootmoeder Spinster. The story is written in two languages, namely Sundanese and Dutch. The book is considered as evidence that the story of Nini Anteh is a very valuable Sundanese cultural heritage, and can be considered the definitive and oldest source of the story of Nyai Anteh. Pleyte wrote that a hunter had a pet cat. One day, the hunter urinated on a coconut shell. Not long after, the urine was drunk by the fluffy white cat. In time, the cat gave birth to a very beautiful baby girl. The hunter then adopted the baby as a child. He treated the baby and the cat well. One day, the hunter remarried. One time, he will return to hunting in the forest and leave the little girl and her pet cat to be well cared for.

The stepmother hated her husband's decendant. Physical abuse he often did to the little girl and the cat. The woman did not know that the white cat was the little girl's biological mother. Once, when she saw her husband coming, she spilled rice crumbs and hit Anteh and the cat on the head with a rice bowl. She lied to her husband that Anteh ate and the cat ate its fill until crumbs of rice spilled over their bodies. The cat will receive the same torment if it fights against the woman. One day, the hunter walked into the forest, while Anteh and his cat went to the river bank. On the bank of the river, there is a nunuk tree whose fruit is very sweet. He sings about the deliciousness of the fruit. Anteh and the cat decided not to return home. Returning from the forest, the father asked about his two favorites. Her stepmother only said that they bathed in the river. By evening, they had not returned. The hunter then followed to the river bank. A melodious hum was heard. The voice followed. To his surprise, the girl and the cat were already at a height. The hunter asked them to get down and return home. They refused. Anteh continued to sing and sing.

Every time Anteh sings, the taller the tree grows until it reaches the moon's surface. The hunter tried to climb up and chase after them. Unfortunately, the distance was too far, so he gave up on letting go of his two favorites. The strange and the cat then lived on 
the moon. The hunter lived in the tree because the distance to return to earth was not possible. Until he died. His death was marked by a puff of white smoke called a latte (one year's misery). Apparently, Anteh's distance from the earth to reach the moon is one year. On the moon, Anteh is cared for by an angel and the ruler of the moon. He got a job weaving. The work is never finished because the woven products are always torn and the thread is cut off. Another version, Ijah TV [22], is depicted as a hunter who completely trusts his stepmother, even becoming less concerned about Anteh and her cat. If Anteh conveyed his stepmother's behavior, the hunter turned to his new wife. The starting point for Anteh's departure was his mother's grave. In that place, he often complained about the tombstone of his mother. Miraculous events occurred, from above his mother's grave, appeared a golden banana. Anteh's body became strong. The change made the stepmother suspicious. When followed, the stepmother rebuked Anteh and accused her of being a thief. He took the banana. Anteh sad cry. By late afternoon, the hunter was looking for Anteh. He found the child was still crying over his fate. The hunter did not succeed in persuading him. Suddenly, from the sky stretched out a rainbow bridge. The angels came down to earth and picked up Anteh. They took Anteh to the moon and took care of her with great care. Just as he was about to leave, from his mother's grave appeared a cat that he brought to the moon.

Herdy's point of view looks more interesting [25]. In "Lunatic", Herdy [25] gives a rather Medieval picture of Anteh's figure. Anteh is described as the youngest girl who is very beautiful. As the youngest child and only daughter, she gets the full attention of her father. However, he had to lose his mother who died shortly after giving birth to Luna. Luna grew up to be the darling of the whole house. Her prominent appearance always attracts the attention of anyone, both women and men. However, that comfortable life just changed. The affection between older brothers for him shifted so far that it led to an open sibling fight. Luna always takes the time to herd a group of her domestic cats up a hill. He contemplated as he looked at the moon. He wants to be the moon. Especially after that embarrassing incident happened. The ruler of the Azog Country where Luna lives then decides to punish Luna because she is considered a source of disaster. In the end, Luna had to receive the death penalty by being burned with all her beloved cats. Since then, the country of Azog has been traumatized by the full moon. At that time, the residents will be struck by extraordinary fear, close the windows tightly, read prayers and scriptures, and experience madness when they see the full moon, as stated in Luna's oath at the end of her life.

\subsection{Kuyang}

Kuyang is a subtle creature in the form of a human without a body. What appears is the head of a woman with a series of hanging internal organs. This ghost appears a lot in Kalimantan. Mbah Roli, on Neng Ijah [22] said that in Wari Village, there once lived a woman named Maharati. The woman was born deformed, did not have a nose bridge. His father then made an artificial nose out of wood. He liked the artificial nose. her two sisters who were born beautiful and perfect praised her a lot. So did his parents. Maharati never left the house and locked himself in the house. This was done by his parents to avoid ridicule from his friends. The atmosphere of the house never made him bored. But one day, he wanted to look outside. He slipped out through the hole in the back wall. He admired the bustling world. There was a man who liked to peek into Maharati's house. He was curious about the woman with the wooden nose. 
A group of girls and boys then communicated and invited him to play. Maharani was afraid to break her parents' rules. However, the girl, who was with her two friends, promised to invite her to play. They will return later in the afternoon to attract Maharani. True that afternoon they managed to pull Maharati out of his house. They invited Maharati to go around the market using a wagon. Coming out of the market, they arrived at a field and invited another child to play with Maharati. The three friends wanted to remove Maharati's artificial nose. Other kids make fun. They purposely framed Maharati for humiliation. Not long after, the father came and chased the children away. Since then, Maharati has been confined.

His parents and brothers tried to persuade Maharati. In the end, Mayang, her sister, brought a rabbit. He was happy to see her. However, he was unable to control his grudge against his friend. He wanted to trap his friends. Maharati invited his three friends, who were still peeking behind the hole, to enter one by one into his house. If there is a crowd he will certainly be rowdy and most likely will not be allowed by his father. The three friends agreed and threw the rope behind the wall. Maharati tethers a rope for his friends to rest on. The first girlfriend came in. Maharati shows the toy he made from wooden roots. Nara was very happy to see the toy. Unbeknownst to him, a fatal blow from a rock ended his life. He put the body in a sack. The next victims are Purok, and Mantir. The three sacks containing the bodies were then dumped in the garbage cart. At the garbage shelter, the corpse will be burned with other garbage so that people believe that he killed the three friends.

Years later, Maharati was allowed out. Now he can buy things in the market. There he met a hunchbacked grandmother. He gave alms to the grandmother. Sometime later, the grandmother then came to him in his yard. He gave an invitation to Maharati to change himself. He promised to change his face to be beautiful, but he only had to drink the blood of a woman who was giving birth. He didn't believe it. However, he witnessed the change in the shape of the grandmother, from an old state to a beautiful one. Maharati was given a magic spell. He slipped under the bed of his neighbor, who was giving birth. Sure enough, the next day he was surprised to see her face. She is very beautiful and almost perfect. Beauty only lasts a month. His face was broken again. Therefore, the mysterious grandmother met him and asked him to eat the baby if he wanted to be beautiful. Maharati dark eyes. He kidnapped the baby who was born here, took him to the forest, killed him, and devoured him viciously. Sure enough, Maharati was again beautiful. After that, the Wari village was stirred up by the kidnapping of babies. One day, Maharati met his fate. He was caught and sentenced to death. His family was evicted from the village and his house was burned. His head was beheaded. However, sometime later, he rose again. She turned into a more beautiful woman. However, the severe wound on his neck did not go away. Maharati at noon mingles in the market. At night, he changes his form into a kuyang ghost that preys on babies.

\subsection{Studying Gender in Female Spirit Characters in the Legend of the Archipelago}

The discussion of gender in the six spirits, namely kuntilanak, Sumiati, Nyi Roro Kidul, Wewe Gombel, Nini Anteh, and Kuyang, has a common thread that shows similarities and differences. The similarities shown by the six figures, during their lifetime, except for Kuyang and Sumiati, were experiencing physical and spiritual torment, precisely from the people who were close to them. Kuntilanak experienced a failure in the birth process that was not handled. The difficulty of health facilities in the 
past was extraordinary. Women who experience difficulties in the delivery process do not necessarily receive prompt treatment so they have to accept a serious risk, namely death. In the case of Ngartasih, she was tortured by the closest environment in a remote village, namely the villagers who held a grudge not against the poor woman, but against her late husband who had acted arbitrarily to the residents. It was not only residents who incidentally were men who attacked him, but also the handling of death carried out by Mbok Rumi. Ngartasih's body was not properly decorated, instead, it was allied with the devil in a ritual ceremony. The torture after torture became Ngartasih's impetus to take revenge indiscriminately. Besides Mbok Rumi as the first victim, most of the villagers were also targeted so that Balangandang village became a dead village. Some of the survivors chose to leave the village and move to another village.

Patriarchal pressure can also be seen in the histories of Nyi Roro Kidul, Wewe Gombel, and Sumiati. The necessity of marriage and, conversely, the unilateral rule of the ancestor towards Nyi Roro Kidul is an unfair treatment for the benefit of the body. The ancestors did not want that Nyi Roro Kidul, who had been prepared as the successor to the throne, would not focus on royal affairs if he married. However, Nyi Roro Kidul showed her resistance, the patriarchal and hegemonic verdict that was inflicted on her prompted the woman to isolate herself from the patriarchal realm. He had to build a new identity with extraordinary sacrifices, namely imprisoned, beyond the long study of magic, and the necessity of taking extreme actions, namely throwing himself into the sea where the waves were fierce. Wewe Gombel experienced domestic violence, both from her mother-in-law and her husband. The inability to produce offspring causes the husband to be dwarfed in public. Sri, who is in a minority position within Jaka's family, is easily the target of acts of violence to the point of tearing her inner wound. Out of his control, he attempted to defend the grudge that was building up in his heart. After the suicide she experienced, she built her confidence as an ideal mother. Although he always kidnaps children who escape the supervision of his parents, Wewe Gombel shows a new identity with his ability to take care of children. Nini Anteh is an illustration of a child's politeness towards his parents. Whatever the version, Anteh always adheres to ethics even in difficult conditions. Anteh can try and study diligently which is described by her ability to weave. Anteh is an independent woman, with abilities in the domestic and public spheres. In the version of ajian saepi that he mastered, it is an illustration that he is thirsty for knowledge, in whatever form it takes.

Sumiati and Kuyang are a brutal depiction of the transformation of women before and after her death. Sumiati suffers the tragic fate of losing her husband. It wasn't long before he experienced the same thing. However, after transforming, she can only reach the perpetrators of the murder of her husband who incidentally she has never met while the perpetrators of the abuse and violence against her cannot be remembered at all. Sumiati can only remember costumes worn by the perpetrators of the rape. Sumiati transforms into a vengeful person, but on the one hand, she becomes a person who tends to be lonely and always hopes for her husband's resurrection. Meanwhile, Kuyang is a transformation of a woman who has never received an award from the public sphere for her entire life. Maharati never accepted his shortcomings and tried to make up for his shortcomings in quite extreme ways, drinking the blood of women who were giving birth and eating newborn babies. Disappointment and lack of proper knowledge cause a Maharati to be vulnerable when faced with problems. His identity has been cornered in the public sphere so he must take revenge. His ambition to become "more" causes him to fall into error. 


\section{Conclusion}

From the biographical exposure and analytical review of the research corpus, the writer can conclude the following points, following the research limitations at the beginning. The women described in the data are weak and are easily cornered by difficult conditions and situations. However, when they have undergone a significant transformation, the women change themselves and can show a new identity, both maternal and brutal. The conflicts that the women encountered were internal and external. Internal conflicts occur in the form of extraordinary acts of violence (both physically and mentally) that lead to the fall of unilateral verdicts and tend to be patriarchal. As a result, the women experienced great trauma and immeasurable grudges that carried with them when they had transformed. The final image of the woman is, the woman becomes alone. He tried, whatever, with his ability, both in the category of good or bad. They work alone, in addition to taking revenge for themselves, as well as revenge for their partner's criminal treatment. Women in life have hidden powers, except for Maharati. However, the power would become uncontrollable once they were transformed.

\section{References}

[1] K. Amstrong, A Short History of Myth. Edinburgh-New York-Melbourne: Cannongate, 2006.

[2] V. Nijman and K. A. I. Nekaris, "The Harry Potter effect: The rise in trade of owls as pets in Java and Bali, Indonesia," Glob. Ecol. Conserv., vol. 11, pp. 84-94, 2017, doi: 10.1016/j.gecco.2017.04.004.

[3] S. Hodgkinson, H. Prins, and J. Stuart-Bennett, "Monsters, madmen... and myths: A critical review of the serial killing literature," Aggress. Violent Behav., vol. 34, pp. 282-289, 2017, doi: https://doi.org/10.1016/j.avb.2016.11.006.

[4] J. Sumardjo, Sunda, Pola Rasionalitas Budaya. Kabupaten Bandung: Kelir, 2011.

[5] A. Rozak, Teologi Kebatinan Sunda. Bandung: Kiblat Buku Utama, 2005.

[6] S. Endraswara, Metodologi Penelitian Antropologi Sastra. Jakarta: Ombak, 2003.

[7] S. Ansolabehere, R. Behr, and S. Iyengar, "Envisioning 'anthropology through design': Adesign interventionist approach to generateanthropological knowledge," Am. Polit. Quarterly, 19, vol. null, no. null, p. 109, 1991.

[8] A. Harini, Yostiani Noor Asmi, dan Rostiyati, “"Keterdidikan Perempuan Sunda dalam Cerita Nini Anteh,", Patanjala, vol. 10, no. 3, pp. 455-470, 2018, doi: http://dx.doi.org/10.30959/patanjala.v10i3.454.

[9] J. Roden, M. Mustafaj, and M. Saleem, "Who else likes it? Perceived gender of social endorsers predicts gender equality support," Comput. Human Behav., vol. 118, p. 106696, 2021, doi: https://doi.org/10.1016/j.chb.2021.106696.

[10] Rori, “Kisah Sebenarnya di Balik Kemunculan Kuntilanak (Cerita Seram). ” Indonesia: https://www.youtube.com, 2020.

[11] N. Omara, “Asal Usul Hantu-Hantu Indonesia.” https://www.youtube.com, 2020.

[12] et. a. Assattira, Azizah, Bausastra Lelembut. Jakarta: Elex Media Komputindo, 2016.

[13] EduNitas, "Ensiklopedia Dunia dalam downloaded 14 Agustus 2021, pukul 05.00 WIB," Ensiklopedia Dunia. EduNitas ITBU Jakarta.

[14] D. Herdy, "Kuntilanak," in Bumi Kuntilanak, Surabaya: UNSApress, 2014, pp. $43--57$. 
[15] R. Saraswati, Gerbang Dialog Danur. Jakarta: Bukune, 2011.

[16] H. A. Kasmana, Kankan, Sabana, Setiawan, Gunawan, Iwan, \& Ahmad, "'Perwujudan Keyakinan akan Keberadaan Mahluk Halus dalam Komik Kawin ka Kunti,'” Panggung, vol. 26, no. 3, p. 280-293, 2016, doi: http://dx.doi.org/10.26742/panggung.v26i3.192.

[17] M. Nababan, "Nyi Roro Kidul Disebut Keturunan Batak, Apa Kata Budayawan?,” https://kumparan.com/, 2021. .

[18] R. Wessing, “"A Princess from Sunda: Some Aspects of Nyi Roro Kidul,” Asian Folkl. Stud., vol. 56, 1997.

[19] R. Riplay, Asal-Usul Wewe Gombel: Hantu Penculik Anak. Indonesia: /www.youtube.com/, 2021.

[20] D. Herdy, “'Dunia Setelah Senja,"” in Bumi Kuntilanak, Surabaya: UNSApress, 2014, p. $33-42$.

[21] Pendongeng, “"Nini Anteh Sang Penjaga Bulan,”" http://dongeng.org/, 2010. [Online]. Available: http://dongeng.org/nyai-anteh-sang-penunggu-bulan/.

[22] Neng Ijah, Carita Nini Antêh dalam downloaded 15 Agustus 2021, pukul 17.39 WIB. Indonesia: Youtube.com, 2021.

[23] E. al. Rahmadhita, Amy, "Nini Antêh anu Ngajaga Bulan" dalam downloaded 15 Agustus 2021, pukul 17.43 WIB. Indonesia: https://www.youtube.com, 2020.

[24] L. N. Karomah, "Perancangan Informasi Cerita Legenda Nini Anteh Melalui buku Komik," UNIKOM, 2018.

[25] D. Herdy, "“Lunatic,"” in Bumi Kuntilanak, Surabaya: UNSApress, 2014, p. 1-12. 